\title{
TARGET AUDIENCE OF LIVE OPERA TRANSMISSIONS \\ TO CINEMA THEATRES FROM THE MARKETING POINT OF VIEW
}

Tahal, R., Stříteský, V.

Opera has a famous history and even the present-day repertoire in opera houses mostly consists of classical and well-known works. Marketers are trying to find new ways that would enable opera lovers all over the world to enjoy top quality performances. One of the most successful models is real-time transmissions of operas to geographically remote cinemas. Cinemas from all around the world participate in the project. In this paper, the authors analyze the spectators' profile and point out differences between North America and the Czech Republic, focusing on transmissions of performances by the Metropolitan Opera in New York. The authors submit a detailed analysis of the socio-demographic characteristics of the spectators and the attendance frequency. Special attention is paid to the marketing profile of Czech spectators, based on primary data gathered in the research. The paper is a combination of research report and business case study. The study reveals that female visitors prevail. Elderly people are also represented in high percentages. The spectators are characterized by refined taste in their lifestyles and familiarity with modern technology.

Keywords: live opera transmissions; event cinema; target audience; marketing profile JEL classification: M31

\section{Introduction}

One of the topical themes of today's marketing is the discussion about customers' profile, target segments, loyalty and repeated purchases. These questions are relevant across all market sectors. This study concentrates on arts marketing and brings the issues of the market research study conducted among cinemagoers and opera lovers. It concentrates on the intercultural comparison between North America and Central Europe (Czech Republic). As a result, it brings the information on the marketing profile of people who visit opera transmissions at cinemas.

The paper is a combination of research report and business case study. It is designed to help both practitioners when developing their marketing decisions and academicians as an incentive to consecutive studies focused on consumer typology.

Opera as a genre has existed for centuries. Nowadays, opera-going is not as popular as it used to be, but still there are people who like to hear and see a classical opera. Specialists in arts management and marketing try to find new and untraditional ways to attract current and potential opera lovers. One of the concepts that has been developed in recent years is based on the idea of bringing the performances from famous opera houses to far away locations. The implementation of this idea has been called "real-time transmission". Performances from famous opera houses are transmitted to cinemas in geographically remote places around the world to audiences for whom it would be either too time-consuming or almost impossible to visit a well-known opera house. It is obvious that opera houses apply modern marketing tools, being fully aware of the necessity to 
actively seek and address spectators, and not remain passive. The Metropolitan Opera's high-definition live movie broadcasts started out with the modest aim of breaking even or not losing much money, at any rate (Thompson, 2012). Arts marketing is thus more and more perceived as one of marketing disciplines with the potential of further development. Arts marketing should acknowledge its foundations in the application of the marketing mix but it needs to move forward on its own terms, based around the interplay of market orientation and market creation within a much wider domain than originally determined (Fillis, 2011). One of the first-class quality opera house that enables such transmissions is the MET (Metropolitan Opera in New York). The MET started to broadcast in 2006, with eight countries participating. The present number of countries all over the world involved with "MET - Live HD cinema cast" has increased to sixty (Metropolitan Opera, 2012).

From the standpoint of cinema owners, the real-time transmissions of operas are understood as "alternative content performances" (as contrasted to the screening of traditional films), and they are also known as a kind of "event cinema" (e.g. Marketing Weekly News, 2013).

The alternative content performances bring numerous advantages for cinemas. Firstly, they attract visitors from different target groups who would never consider visiting a cinema at all. Secondly, cinemas charge a premium price for premium alternative content (Ellingson, 2012).

The event cinema is not a large segment of the market, but it is growing remarkably. Globally, the market for alternative content cinemas was worth $\$ 45.7 \mathrm{~m}$ in 2008 , equivalent to 0.4 percent of gross global box office revenues (PR Newswire, 2010).

This is a great opportunity to reach new target groups of visitors. Cinemas have started to screen everything from live opera and ballet to rock concerts and sports. (Cookson, 2013). The alternative content cinema includes a very wide range of entertainment, apart from traditional films.

Being located in Central Europe, the Czech Republic (sometimes referred to as the "heart of Europe"), and especially its capital city Prague, is famous for its cultural past and present. The Aero Cinema in Prague was the very first one in Central and Eastern Europe that participated. This type of event cinema has become very popular. Nowadays three Prague cinemas belonging to the Aero group are participating, and cinemas in other cities have been gradually joining the project. Even the numbers of spectators increase year by year, from 3.4 thousand in the 2007/08 season to 32.7 thousand in the 2012/13 season.

This paper is a result of project cooperation between the Marketing Department of the University of Economics, Prague, and Aero Cinema. The purpose was to analyze the differences in the structure of spectators between North America, which is the cradle of the idea, and the locality of the Aero Cinema, i.e. Prague, the capital of the Czech Republic, and to describe the profile of the Czech spectators from the viewpoint of their lifestyles.

This paper brings information on the socio-demographic profile of MET - Live HD cinema cast audiences in the Czech Republic and makes comparison with the data presented by a reputable research institute in North America.

\section{Research Goals and Method}

The information delivered by this study should help the marketing managers of the cinemas to become acquainted with the target audience profile and to apply the data in marketing communication. 
The paper has two main research goals:

1. To describe differences in the socio-demographic profile of MET - Live HD cinema cast spectators in North America and in the Czech Republic.

2. To describe the spectators of MET real-time transmissions in the Czech Republic, particularly, finding out the characteristics of a typical spectator from the viewpoint of his/her lifestyle, consumer behavior and relations to other branches of art.

The authors have been cooperating with the Aerofilms company. Besides many other activities, the Aerofilms company is responsible for live transmissions from the MET Live in HD at three Prague cinema houses: Kino Světozor, Kino Aero and CineStar Praha Anděl. All the three cinemas hold the MET transmissions simultaneously, meaning they do not alternate.

The researchers gathered information about socio-demographic characteristics of the spectators and about their life styles. This type of information has never been, with regards to MET - Live in HD, collected and analyzed before.

The data collection was carried out by means of face-to-face questioning during performances at the three cinemas (at intermissions and also at the end of the program). In total, 129 interviews were realized. Details are summarized in Table 1. The interviewers applied systematic sampling methods. Besides the structured questioning, the interviewers were also instructed to carry out their own observation and, if possible, to provide some soft information that might be interesting when extending hard data.

Table 1 | Data collection details

\begin{tabular}{|l|l|}
\hline Characteristic & \multicolumn{1}{|c|}{ Survey value/description } \\
\hline Population & Live HD cinema cast spectators at performing venues \\
\hline Sampling method & Systematic sampling \\
\hline Sample size & 129 \\
\hline Sampling date/period & March, April 2014 \\
\hline $\begin{array}{l}\text { Locations } \\
\text { (numb. of interviews) }\end{array}$ & Kino Světozor (49), Kino Aero (30), CineStar Praha Anděl (50) \\
\hline Survey method & Face to face interviewing \\
\hline
\end{tabular}

Source: Authors

Based on the absolute frequency of the respondents' answers, the relative frequency was analyzed in our calculations. As the statistical method, the chi-square test was used. Further on, the data collected by the Shugoll Research Company (USA, New York) was used. The study focuses just on the MET - Live HD cinema casts in the US. The Shugoll research, also based on questionnaires, was conducted during live HD opera transmissions among respondents in 263 cinemas. It was carried out in autumn 2008 and brought the socio-demographic picture of the MET - Live HD cinema cast spectators in North America (in case of this survey it covers the US and Canada). 


\section{Results and Findings}

Similarities were found in the gender structure of the MET - Live HD cinema cast in the Czech Republic and in the US and Canada. In both geographic areas, women prevail. In the Czech Republic, the female representation is even more significant. In the Czech Republic, the MET - Live HD cinema cast audiences consist of $71 \%$ females and $29 \%$ males; in North America, the audiences consist of 53\% females and 47\% males. (It is worth mentioning that common population structure is $51 \%$ female and $49 \%$ male.)

The data was analyzed by means of a chi-squared test. The survey of gender and age percentage in the two localities, including the results of the statistical test, are presented in Table 2. As far as the age structure of the spectators is concerned, two bands were taken into consideration, i.e. below 50 and above 50 .

Table 2 | Comparison of gender and age structure of MET - Live HD performances spectators

\begin{tabular}{|l|c|c|}
\hline & Czech Republic & North America \\
\hline Male & $29 \%$ & $47 \%$ \\
\hline Female & $71 \%$ & $53 \%$ \\
\hline chi-square test result & \multicolumn{2}{|c|}{15.645} \\
\hline$<50$ years of age & $37 \%$ & $19 \%$ \\
\hline$>50$ years of age & $63 \%$ & $81 \%$ \\
\hline chi-square test result & \multicolumn{2}{|c|}{27.793} \\
\hline
\end{tabular}

Source: Authors, Van Eeden (2011).

The resulting value of the chi-squared test ( 2 degrees of freedom) in both cases is higher than the critical value $(5,991)$, significant at $\alpha=0.05$. It can be concluded that there are statistically significant value differences in each of the two localities.

A highly important factor for marketers is the customer loyalty. This study recorded the percent of spectators attending the event for the first time or once in the season, and those attending the MET - Live HD cinema casts repeatedly, i.e. several times in the season. The results for the two above mentioned localities are presented in Table 3.

Table 3 | Comparison of the spectators' attendance at MET - Live HD performances

\begin{tabular}{|l|c|c|}
\hline & Czech Republic & North America \\
\hline First, or once per season & $39 \%$ & $16 \%$ \\
\hline Twice or more per season & $61 \%$ & $84 \%$ \\
\hline chi-square test result & \multicolumn{2}{|c|}{17,553} \\
\hline
\end{tabular}

Source: Authors, Van Eeden (2011). 
Just the same as in the previous calculation, the resulting value of the chi-squared test ( 2 degrees of freedom) is higher than the critical value $(17,553)$, significant at $\alpha=$ 0.05 . It can be concluded that there are statistically significant value differences in each of the two localities.

The following paragraphs bring the information on the characteristics of the MET - Live HD cinema event audience in the Czech Republic. Further on, the overall satisfaction with the performance was investigated and, for the marketing purposes, the lifestyle and consumer behavior profile of spectators was drawn up, based on the primary data obtained by our research.

The question of the attendance frequency is closely connected with the declared satisfaction. We can presume direct relations between the two factors. Enthusiastic and satisfied people will surely tend to become more loyal and frequent spectators than those who found the performance boring. In the survey we used the four-step verbal (Likert) scale "Strongly satisfied", "Somewhat satisfied", "Somewhat dissatisfied", "Strongly dissatisfied".

The percentage distribution shows high satisfaction with the overall quality. Eighty percent of the spectators were satisfied and out of them $71 \%$ were strongly satisfied. Those who declared that they were somewhat dissatisfied added the commentary that their dissatisfaction was not caused by the artistic quality of the MET performance, but it predominantly resulted from technical parameters of the cinema (subtitle quality, seats, foyer bar, etc.). As a footnote, we can mention that the interviewers participating in our research (young people professionally engaged in arts and marketing) were happy with the performances and commented their activities not as a job but as a fantastic professional and life experience.

Further on, we examined the motivation for attending this type of performance. We used a half closed multiple-choice question.

When analyzing the data we found an interesting fact, namely that the respondents who answered "I wanted to try something new" in $81 \%$ also ticked the choice "I am an opera lover"; $56 \%$ of those who "wanted to try something new" were attending the performance for the first time and $72 \%$ of them were strongly or somewhat satisfied with the performance. All these factors indicate a great client potential of this type of performances in the future.

Finally, we wanted to establish the lifestyle and consumer behavior profile of the Czech Republic MET - Live HD cinema cast spectators. We offered each respondent seventeen statements that may characterize the life in modern society. The statements covered topics concerning culture, the use of modern technology, social life and some others. The bipolar-choice question was used for this purpose; it means that each respondent was asked to answer the statements "yes" or "no".

The lifestyle concept, partly because of its intuitive appeal and rather obvious relationship to consumer behavior, has received a considerable amount of attention in the marketing (Anderson, 1984).

In our survey we used 17 statements in total. In Table 4, we group all these attributes into three clusters. The first cluster contains attributes that were agreed by more than $70 \%$ of the respondents, the second cluster contains quite neutral attributes and the third one brings the attributes that are not typical for the Czech Republic MET - Live HD cinema cast visitors, it means those that were agreed by less than $40 \%$ of the respondents. 


\begin{tabular}{|l|l|}
\hline \multicolumn{1}{|c|}{ Attributes } & \multicolumn{1}{c|}{ Statements } \\
\hline $\begin{array}{l}\text { Characteristic attributes } \\
(>70 \% \text { agreed) }\end{array}$ & $\begin{array}{l}\text { I like reading books (86\%) } \\
\text { I like classical music concerts (84\%) } \\
\text { I like going to good restaurants with a couple of friends (83\%) } \\
\text { I use payment cards (81\%) } \\
\text { I use the internet (81\%) } \\
\text { I like live opera (80\%) } \\
\text { I like visiting exhibitions (79\%) } \\
\text { I like theatre drama plays (76\%) }\end{array}$ \\
\hline $\begin{array}{l}\text { Neutral attributes } \\
\text { (from 40\% to 69\% agreed) }\end{array}$ & $\begin{array}{l}\text { I like watching TV (62\%) } \\
\text { I visit ballet in the theatre (59\%) } \\
\text { I am interested in architecture (59\%) } \\
\text { I am interested in sports (57\%) } \\
\text { I like shopping (42\%) }\end{array}$ \\
\hline $\begin{array}{l}\text { Non-characteristic } \\
\text { attributes } \\
(<40 \% \text { agreed) }\end{array}$ & $\begin{array}{l}\text { I visit popular music concerts (38\%) } \\
\text { I visit musicals in the theatre (31\%) } \\
\text { I like brand clothing (30\%) } \\
\text { I go to fast-food places (12\%) }\end{array}$ \\
\hline
\end{tabular}

Source: Authors

Based on these statements (and on the socio-demographic characteristics that are interpreted in the following chapter), we can imagine the typical Czech Republic MET - Live HD cinema cast visitor as a mature, educated lady, well dressed, not necessarily in brand clothes, fond of books, familiar with modern technologies like the Internet or payment cards, in her leisure time listening to classical music, discussing cultural topics with a couple of friends in a good restaurant or café.

For the opera lovers, it is not characteristic to do shopping due to "having nothing to do". Opera lovers do not frequently listen to popular music or to musicals.

An interesting finding is that among the non-characteristic attributes dominates the statement "I go to fast-food places" that was agreed only by $12 \%$ of the respondents. (When talking about these, $12 \%$ of people who like fast-food, they are represented by all the age categories; not significantly by the young generation as it could be presupposed.) This brings a conclusion that from the marketing point of view the opera lovers are a clearly defined segment of population in respect of their lifestyle and consumer behavior.

\section{Discussion and Conclusions}

The paper is based on primary data of a research project that was carried out for marketing purpose of the Aerofilms company. The study belongs to the first ones of its kind in the Czech Republic. Real time opera transmissions have become popular all around the world. The numbers of participating cinemas and the number of spectators have been constantly increasing. Nowadays, 1,900 cinemas participate worldwide, and the total audience in 2012 reached 2.95 million (Metropolitan Opera, 2012).

It is necessary to know the customers' profiles not only in the sector of consumer goods, but even in the sector of service, which in our case applies to arts marketing. The 
information resulting from our research - including the demographic profile of the spectators, their consumer behavior, their lifestyle characteristics, attitude towards various artistic genres - form the background for better-aimed market targeting and communication.

It may be interesting to compare the structure of spectators in the Czech Republic and in North America. Significant differences can be observed in gender and age structures. The results can be summarized by stating that in the Czech Republic, the MET - Live HD cinema cast audiences are dominated by females, and the events are attended even by younger persons, whereas in North America, the genders are represented equally, and elderly people are more frequent among the spectators.

The primary data for the Czech Republic was gathered in 2014, while the data concerning the American spectators are based on research carried out in 2008. Despite this fact, it is improbable that the structure of spectators has undergone abrupt changes.

\section{References}

Anderson Jr, W. T., \& Golden, L. L. (1984). Lifestyle and Psychographics: a Critical Review and Recommendation. Advances in Consumer Research, 15(11), 405-411.

Cookson, R. (2013). Alternative content at cinemas draws in the masses. Financial Times, 14.

Czech Statistical Office (2014). Age Structure of the Czech Population. Retrieved February 2, 2016, from http://www.czso.cz/animgraf/cz/.

Ellingson, A. (2012). What audiences want. Boxoffice, 148(10), 24-26.

Event Cinema Association (2013). Event cinema in European cinemas. Retrieved January 3, 2016, from http://www.eventcinemaassociation.org/assets/eca-screendigestreport 2013.pdf.

Fillis, I. (2011). The evolution and development of arts marketing research. Arts Marketing, 1(1), $11-25$.

Marketing Weekly News (2013). Advertising and marketing companies; "pompeii from the british museum" brings ancient roman history to life in exclusive cinema event, Marketing Weekly News, 18.

Metropolitan Opera (2012). Press fact sheet 2012-13. Retrieved January 12, 2016, from http://www.manisteemi.gov/DocumentCenter/View/900.

Motion Picture Association of America (2013). Theatrical Market Statistics. Retrieved January 12, 2016, from http://www.mpaa.org/wp-content/uploads/2014/03/MPAA-TheatricalMarket-Statistics-2013_032514-v2.pdf.

National Opera Center (2008). The Metropolitan Opera Live in HD - Who Attends, and Why. Retrieved January 12, 2016, from http://www.operaamerica.org/content/research/ Met\%20HD\%20Article.pdf.

Thompson, W. (2012). Met opera's live HD broadcasts profitable. Buffalo News. Retrieved January 8, 2016, from http://search.proquest.com/docview/926425179?accountid=17203.

PR Newswire (2010). Reportlinker adds alternative content in cinemas: Market assessment and forecasts to 2014. Retrieved January 8, 2016 from http://www.prnewswire.com/ news-releases/reportlinker-adds-alternative-content-in-cinemas-market-assessment-andforecasts-to-2014-81224772.html.

Van Eeden, S. (2011). The Impact of The Met: Live in HD on Local Opera Attendance. Doctoral dissertation. Vancouver: University of British Columbia . 


\section{Authors}

Mgr. Radek Tahal, Ph.D.

Assistant Professor

Department of Marketing

Faculty of Business Administration, University of Economics, Prague

W. Churchill Sq. 4, 13067 Prague, Czech Republic

radek.tahal@vse.cz

doc. Ing. Václav Stř́íteský, Ph.D.

Assistant Professor

Department of Marketing

Faculty of Business Administration, University of Economics, Prague

W. Churchill Sq. 4, 13067 Prague, Czech Republic

vaclav.stritesky@vse.cz 